УДК 35.082 .37

DOI: $10.33099 / 2707-1383-2019-34-4-128-140$

Думенко М. П., кандидат військових наук, периий заступник начальника Головного управління персоналу Генерального штабу Збройних Сил Украйни (м. Кй̈в)

ORCID: 0000-0001-5633-7700

\title{
ФУНКЦІОНУВАННЯ СЛУЖБ (ПІДРОДІЛІВ) ПЕРСОНАЛУ ЗБРОЙНИХ СИЛ УКРАЇНИ У 2011-2018 РОКАХ В УМОВАХ МИРНОГО ЧАСУ ТА ОСОБЛИВОГО ПЕРІОДУ
}

У статті проаналізовано функиіонування спужб (підрозділів) персоналу в структурі 3С Украйни на основі їх практичної діяльності протягом 20112018 років в умовах мирного часу і особливого періоду та їх вплив на виконання ЗС Украйни завдань за призначенням.

Наведено очікувані результати аналізу, які можуть посприяти виріменню питання щодо визначення кількісних показників итатної чисельності служб (nідрозділів) персоналу 3С Украйни, для своєчасного виконання ними заходів укомплектування, навчання, супроводження, використання військовослужбовців під час проходження військової служби.

Ключові слова: військова кадрова політика, кадрова робота, служби (підрозділи) персоналу, підбір та розстановка кадрів, особливий період.

Постановка проблеми. Станом на початок 2011 року особовий склад ЗС України налічував 200 тис. осіб, у тому числі 150 тис. військовослужбовців, на кінець року - 192 тис., із них 144 тис. - військовослужбовців. Протягом року було скорочено 8 тис. осіб, із них 6 тис. - військовослужбовці. У 2012 році в ЗС України налічувалося вже 184 тис. осіб, з них 139 тис. військовослужбовців, а у 2013 році цей показник дорівнював 165,5 тис. $\mathrm{i}$ 120,9 тис., відповідно [1, с. 23-26, c. 15, c. 33].

Показник звільнення особового складу ЗС України протягом 20112013 років складає $18 \%$.

Передовими країнами світу розглядається орієнтовний критичний показник звільнення персоналу протя- 
гом року $-5 \%$. Якщо він перевищує вказаний цифровий показник, тоді військова організаційна структура зазнає професійних втрат, а на відновлення (введення в стрій, перенавчання, навчання) Знадобляться роки чітко спрямованої діяльності.

Проведення реформування та розвитку 3С України у ці роки визначались відповідно до завдань Воєнної доктрини України та проводились в рамках встановленої Верховною Радою Украӥни граничної чисельності особового складу 3С України.

Воєнна доктрина України у зазначені роки мала оборонний характер і не передбачала імовірного противника. Ко- шти на утримання та розвиток 3С України виділялись, виходячи зі спроможності країни і складали біля 1 \% валового внутрішнього продукту країни [2, с. 10].

Діяльність державних керівників по відношенню до ЗС України у ті роки демонструє головний критерій - це розмір загального економічного ефекту, який виражався у мільйонах гривень.

Подальший перебіг подій показав певні прорахунки у розбудові ЗС України та управління у військовій сфері, зокрема недостатнє фінансування 3С України, що вплинуло на безпосередню діяльність служб (підрозділів) персоналу, оцінку їх спроможності виконувати завдання за призначенням

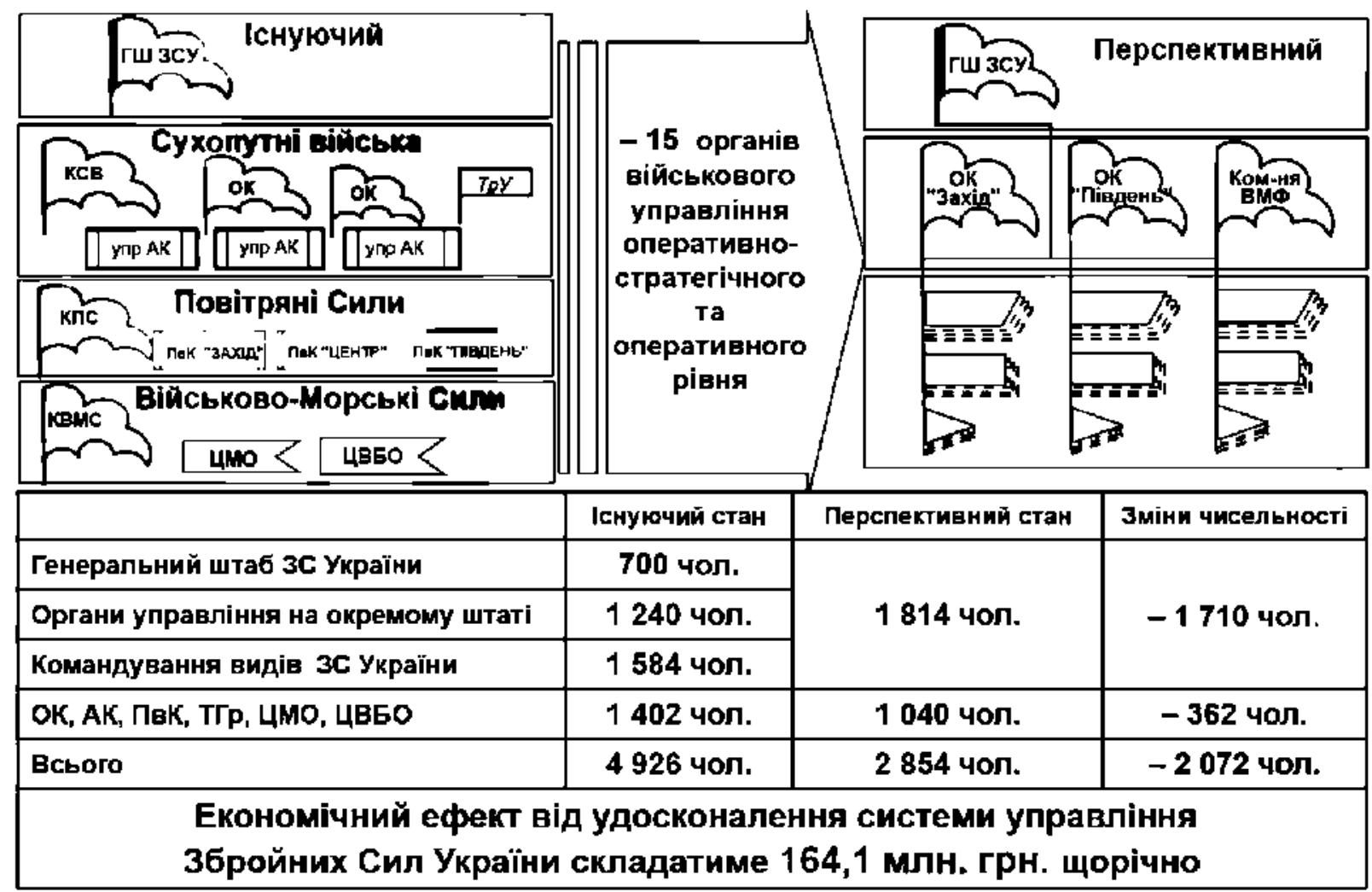

Рис. 1.

Скорочення органів військового управління ЗС України до 2014 року 
під час проведення організаційних заходів до 2014 року стосовно скорочення чисельності особового складу 3С України, а саме: об'єднання військових комісаріатів, зменшення державного замовлення на підготовку осіб офіцерського складу тактичного рівня, знецінення соціальної складової (авторитет, престиж) військовослужбовців та виконання громадянами України військового обов'язку [3].

Підтверджуючим фактом служить рис.1 щодо скорочення органів військового управління ЗС України.

У наступні роки до 2017 року планувалося привести показники штатної чисельності особового складу ЗС України та співвідношення їх категорій до рівня 100 тис. осіб, iз них: 85 тис. військовослужбовців, офіцери - 20880 осіб, сержанти (солдати) - 59120 осіб.

Довідково. Загалом у 2012-2017 роках звільненню 3 військової служби підлягали понад 15 тис. офіцерів.

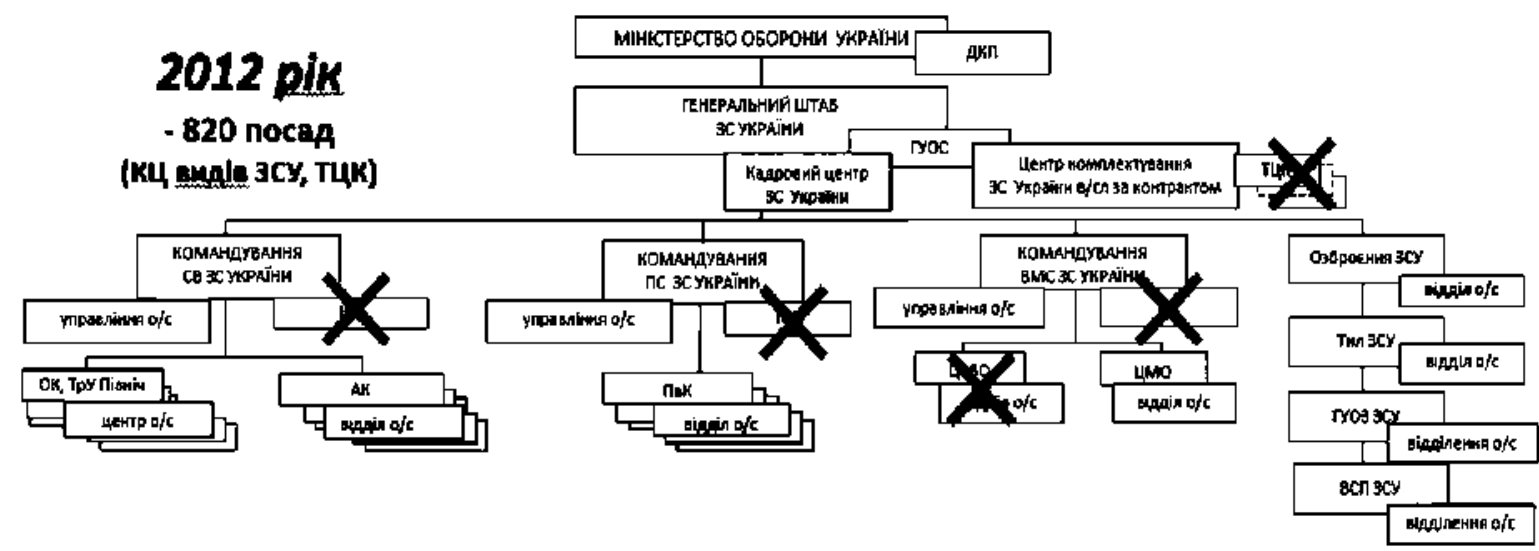

Рис. 2

Структура органів військового управління 3С України у 2012 році

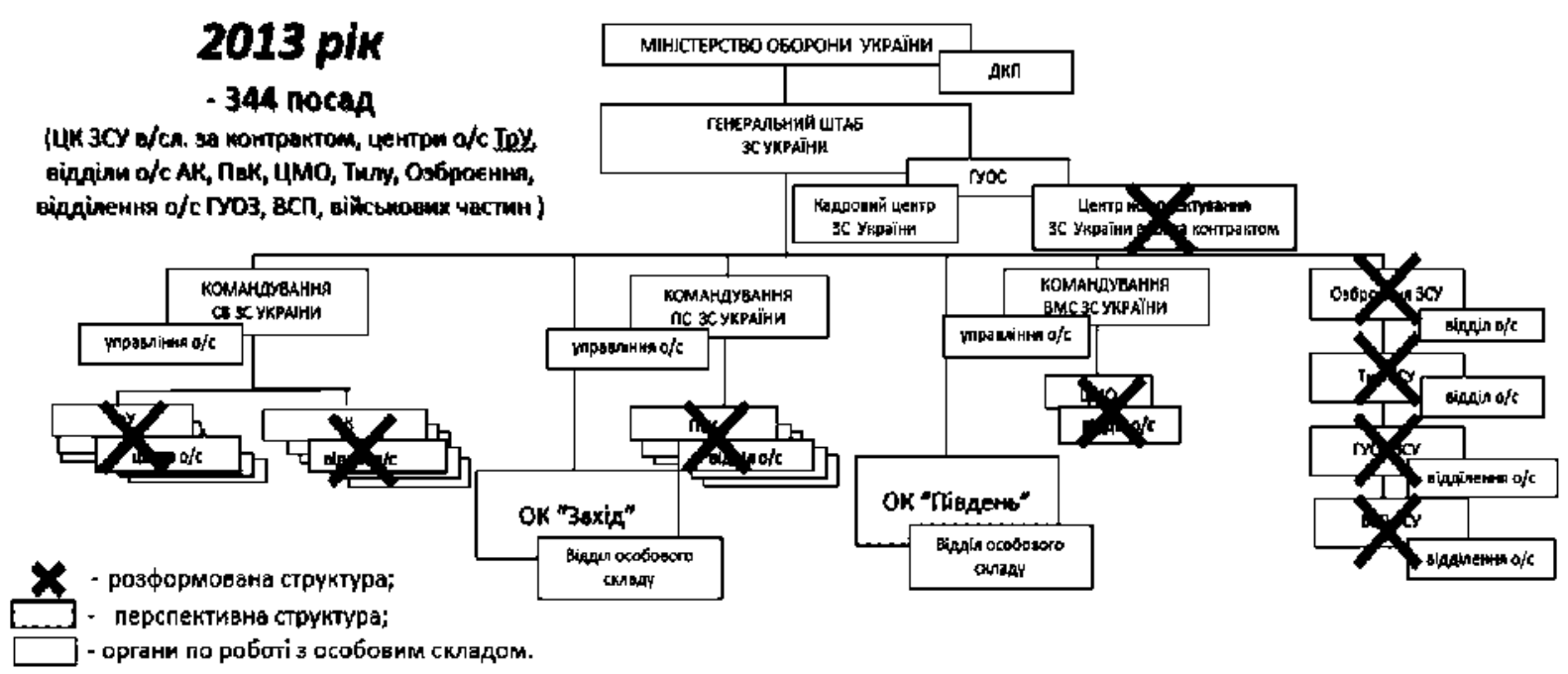

Pис. 3.

Структура органів військового управління 3С України у 2013 році 


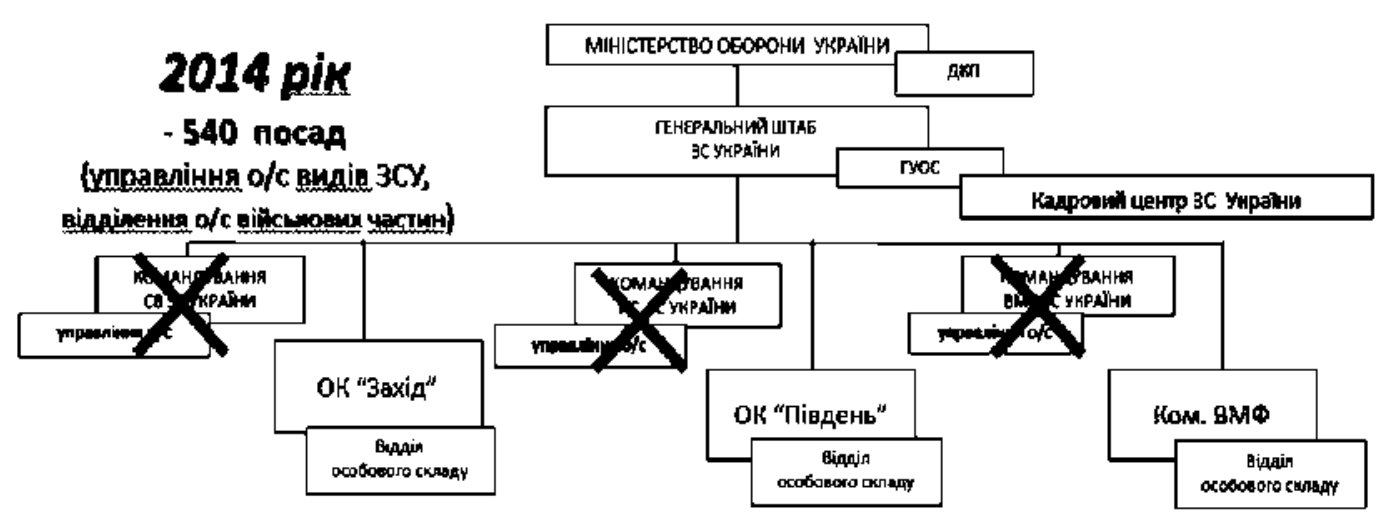

Рис. 4.

Структура органів військового управління 3С України у 2014 році

Аналіз останніх досліджень. За вказаною темою у надрукованих відкритих джерелах досліджень не виявлено.

Метою статті $\epsilon$ проведення аналізу стану справ щодо функціонування служб (підрозділів) персоналу в умовах мирного стану та особливого періоду. Дослідження проблемних питань, прорахунків та причин, які сприяли їх виникненню.

Викладення основного матеріалу. Відповідно до визначених державних програм оптимізації особового складу 3С України не обійшлося і без кардинальних змін системи функціонування служб (підрозділів) персоналу [4].

За період 2012-2014 років зменшено кількість структур служб (підрозділів) персоналу, які здійснювали управління кар'єрою та облік особового складу. Результати скорочення наведені на рис. $2-4$.

У 2012 році було скорочено 820 посад (рис. 2).
У 2013 році було скорочено 344 посади (рис. 3).

На 2014 рік було сплановано скоротити 540 посад (рис. 4).

Загалом, планувалося завершення оптимізації структур до 2017 року та скорочення служб (підрозділів) персоналу у 3,2 раза $(70 \%)[1$, с. $13-16]$.

Необгрунтоване скорочення ЗС України у 2012-2014 роках призвело до того, що служби (підрозділи) персоналу не мали достатньої кількості та досвіду роботи щодо прийому, розміщення та обліку особового складу, який вийшов iз АР Крим. У результаті такого скорочення у стислі терміни здійснено розробку нових нормативно-правових актів та перегляду загальної чисельності служб (підрозділів) персоналу ЗС України.

3 початком проведення АТО прийнято рішення про створення нових організаційно-штатних структур, які були націлені на формування органів 


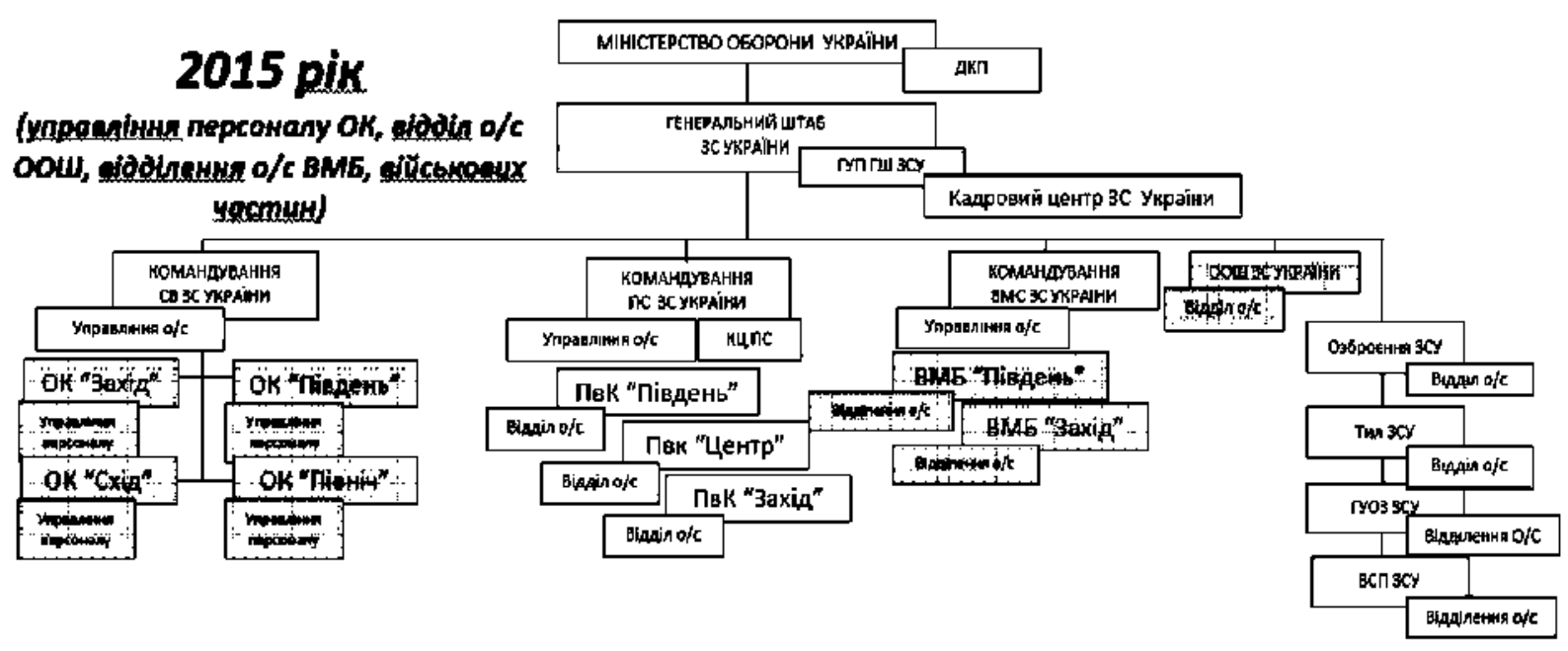

Рис. 5

Структура органів військового управління ЗС України у 2015 році.

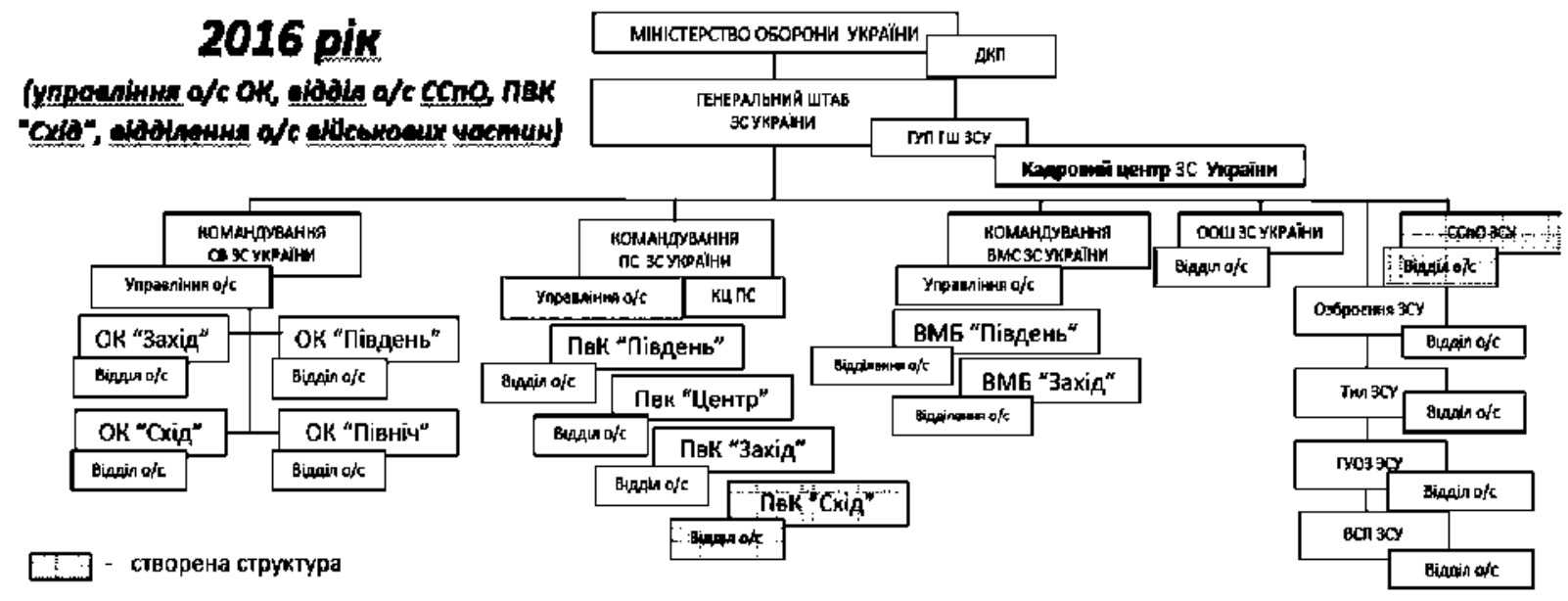

Рис. 6.

Структура органів військового управління ЗС України у 2016 році

військового управління, військових частин, підрозділів для першочергового забезпечення захисту громадян та територіальної цілісності держави. Реформування служб (підрозділів) персоналу наведені на рис. 5-8 $[1$, c. $16 .$, c. $8-10$, c. $13-16$, c. $20-25]$.

У 2015 році сформовано: управління персоналу оперативних командувань, відділ особового складу об'єднаного забезпечення, підрозділи для охорони оперативного штабу ЗС України, відді- аеродромів і стартових позицій зеніт- 
них ракетних військ, відновлено діяльність 138 районних та міських військових комісаріатів.

У 2016 році сформовано: управління особового складу оперативних командувань, відділ особового складу Сил спеціальних операцій, повітряних командувань Повітряних Сил 3С України, відділення особового складу військових частин (рис.6).

Крім того, у 2016 році сформовано: управління повітряного командування “Схід" Повітряних Сил ЗС України, кадр корпусу резерву, три кадри бригад, чотири полки та 12 батальйонів (дивізіонів), розпочато уніфікування штатів 89 військових частин бойового складу.

На кінець 2016 року загальна чисельність 3С України становила 250 тис. осіб, у тому числі 204 тис. військовослужбовців та 46 тис. працівників ЗС України.
У 2017 році сформовано: кадровий центр Сухопутних військ ЗС України, управління персоналу Сил спеціальних операцій ЗС України, відділення персоналу кадру корпусу резерву, відділення особового складу військових частин (рис.7).

Крім того, у 2017 році сформовано: військові частини кадру корпусу резерву, навчальний механізований полк, навчальний центр, два окремі гірсько-штурмові батальйони, два окремі автомобільні батальйони, окремий вузол радіоелектронної боротьби, дві картографічні частини, зенітний ракетний підрозділ, окремий центр радіо і радіотехнічної розвідки, окремий батальйон морської піхоти, чотири екіпажі малих броньованих артилерійських катерів.

Загалом протягом 2016-2017 років у 3С України уніфіковано штати ста тринадцяти бойових частин: П’ятдесяти

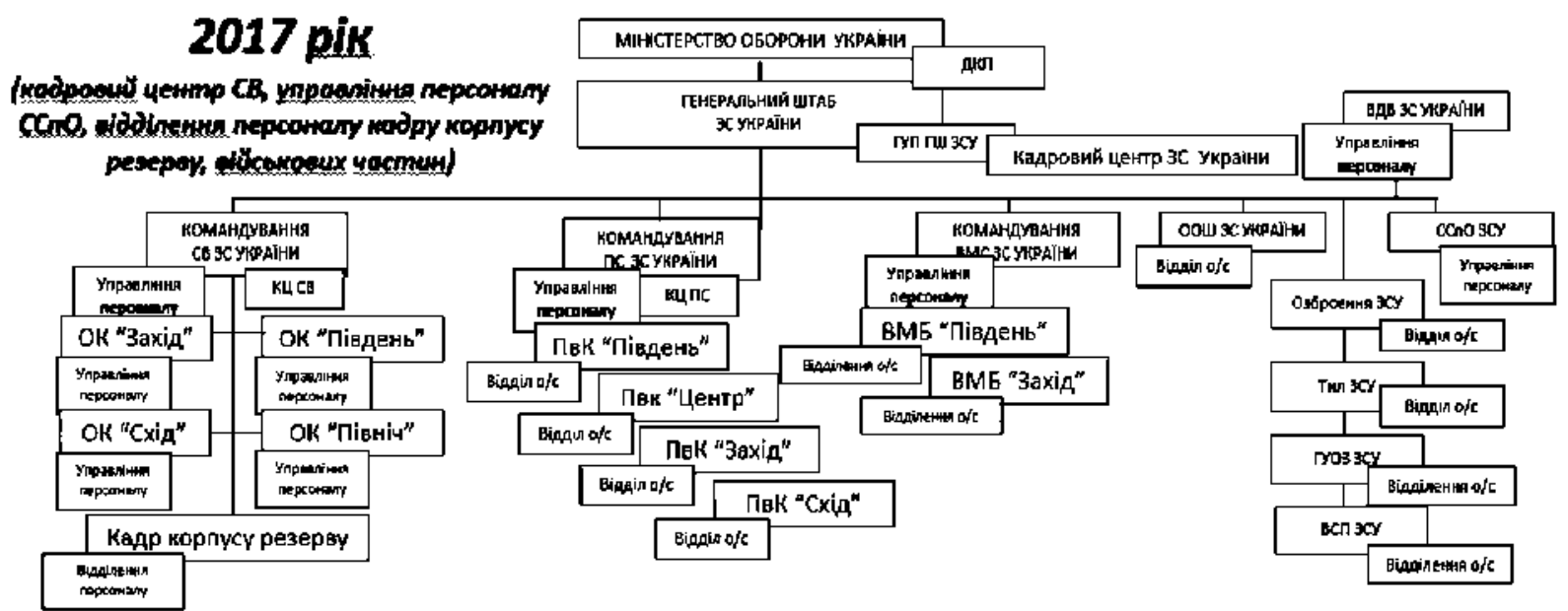

Puc. 7.

Структура органів військового управління ЗС України у 2017 році 


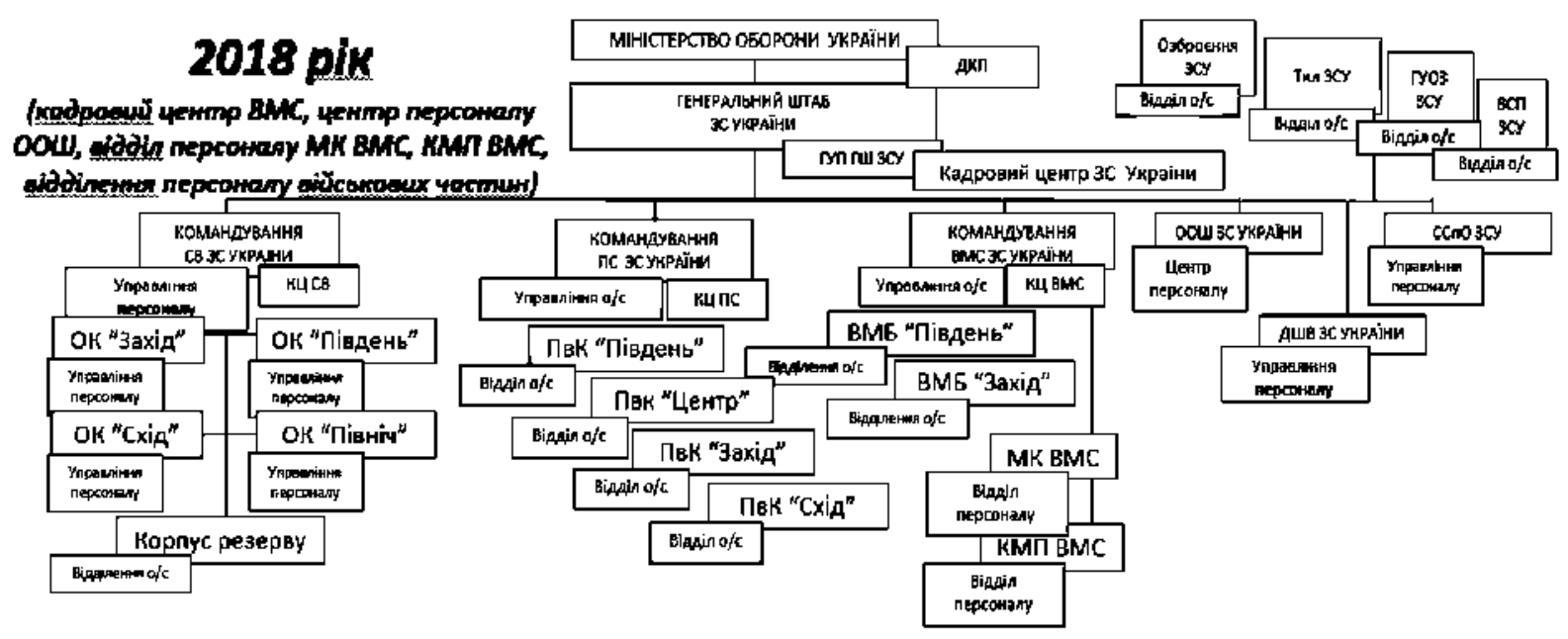

Рис. 8

Структура органів військового управління ЗС України у 2018 році

п'яти бригад, дев'ятнадцяти полків, тридцяти семи окремих батальйонів та двох батальйонних тактичних груп [1, c. 8-10, c. 13-16].

У 2018 році сформовано: кадровий центр Військово-Морських Сил, морське Командування та Командування морської піхоти Військово-Морських Сил (крім того - 23 кадри бригад територіальної оборони) (рис. 8).

Разом із формуванням нових та переходу існуючих військових частин на штати воєнного часу в умовах обмеження зазначених фахівців на посади вимушено призначались особи без відповідного досвіду роботи та необхідної підготовки.

У зв'язку із зазначеним, вживалися заходи щодо підсилення в районі проведення АТО на території Донецької та Луганської областей складової частки фахівців служб (підрозділів) персоналу не на постійній основі, а шляхом відкомандирування, у першу чергу офіцерів з Головного управління персоналу Генерального штабу ЗС України та Кадрового центру ЗС України до служб (підрозділів) персоналу секторів (оперативно-тактичних угруповань).

3 початком активної фази проведення АТО внесено зміни до наказу Міністерства оборони України, завдяки чому було розширено повноваження по номенклатурі для більш оперативного прийняття кадрових рішень командирами щодо переміщення та призначення особового складу на посади [5].

Аналіз роботи служб персоналу під час проведення АТО викрив низку слабких сторін та недоліків функціонування системи військового обліку призовників та військовозобов'язаних. Останні негативно вплинули на рівень забезпечення органів військового управління своєчасними та достовірними даними про персональний кіль- 
кісно-якісний склад людських мобілізаційних ресурсів. Зазначене, у свою чергу, призвело до збільшення часових показників проведення планування та відтермінування у здійсненні заходів щодо переведення ЗС України та правоохоронних органів спеціального призначення на організацію і штати воєнного часу та доукомплектування ix особовим складом як у мирний час, так і в особливий період.

Відсутність достатньої кількості фахівців та призначення командирами посадових осіб, відповідальних за кадрову роботу військової частини, без знання та вміння застосовувати у повсякденній діяльності керівні документи з питань організації кадрової роботи, призводило до зволікань при прийнятті кадрових рішень.

Водночас плинність (ротація) особового складу у військових частинах, залучених до проведення АТО, складала високу частку (демобілізація, звільнення за станом здоров'я тощо). Призначення особового складу на вакантні посади для укомплектування в деяких випадках здійснювалось не виважено. Характерним було не врахування резерву кандидатів для просування по службi, рівня військової освіти та набутого практичного досвіду [6, с. 200-2011].

Одним із прикладів усунення зазначеного були започатковані коротко- строкові курси для осіб рядового та сержантського складу з вищою освітою 3 подальшим присвоєнням первинного військового звання "молодший лейтенант" та призначенням на первинні посади офіцерського складу для повної реалізації професійного потенціалу військовослужбовців [7, с. 163-173].

Значне збільшення чисельності особового складу та особливість застосування військових частин негативно вплинули на здатність виконувати поставлені завдання.

Встановлено, що штатна чисельність військових частин (підрозділів) 3 переходом на штати воєнного часу зростала від 0,5 до 3 разів, в той же час чисельність служб (підрозділів) персоналу в більшості випадків залишалася без змін. У кращому випадку доукомплектування здійснювалося однією посадою на рівні відповідального виконавця, або навпаки були випадки зменшення кількісного показника.

За аналізом військових науковців шляхами вирішення кадрових питань в роботі кадрових органів 3 переходом на штати воєнного часу вважається за доцільне збільшення іх штатної чисельності, зокрема, окремий батальйон - на одну посаду (діловод) або бригада (полк) - на кожну тисячу посад - одна посада (відповідальний виконавець) [8, с. 121-126]. 
Як результат, зміни організаційноштатних структур служб (підрозділів) персоналу, скорочення їх чисельності до показників мінімально-достатньої доцільності значно знизили ефективність кадрової роботи 3 питань обліку та формування командному складу раціональних пропозицій ефективного використання особового складу.

Висновок. Проведений аналіз та розгляд питань функціонування служб (підрозділів) персоналу в структурі ЗС України протягом 2011-2018 років в умовах мирного часу та особливого періоду дозволили засвідчити не тільки наявність постійного взаємозв'язку таких складових, що впливають на виконання завдань за призначенням 3С України, як укомплектованість та проведення кадрової роботи, але і потребу у необхідності продовження наукового дослідження щодо встановлення співвідношення чисельності служб (підрозділів) персоналу до штату особового складу.

Водночас, стабільність та зменшення кількісного показника структур служб (підрозділів) персоналу під час збільшення особового складу при переході на штати воєнного часу призводить до зниження організаційно-якісного рівня кадрової роботи.

Як негатив слід відмітити незмінне значення кількісного показника служб (підрозділів) персоналу при одночасному збільшенні особового складу від 0,5 до 3 разів під час переходу на штати воєнного часу.

Широкоспектрові завдання, які характеризують кадрову ситуацію, 3 одного боку, та необхідність вирішення питань прийняття на військову службу, призначення на посади за військовообліковою спеціальністю, просування по службі, супроводження кар'єрного зростання та звільнення військовослужбовців, можливі комунікації, виконання інших документів потребують детального дослідження часових показників діяльності осіб, відповідальних за виконання функщіональних обов'язків служб (підрозділів) персоналу. Це надасть змогу обгрунтовано встановити пороговий (мінімальний) рівень чисельності зазначених осіб та розв' язати суперечності щодо доречної доцільності цього показника.

На жаль, аналіз засвідчив превалювання ручного режиму реалізації воєнної кадрової політики в підходах формування та визначення кількісних показників штатної та списочної чисельності служб (підрозділів) персоналу, який формується за принципом вибіркового підходу, що грунтується на особистих думках, а також набутого практичного досвіду командирів та начальників. При цьому в більшості 
випадків скептично сприймаються теоретичні напрацювання.

Цьому сприяють висновки наукових досліджень 3 питань комплектування служб (підрозділів) персоналу, які проведено військовими науковцями. Так, шляхами вирішення кадрових питань в роботі служб (підрозділів) персоналу з переходом на штати воєнного часу вважається за доцільне збільшення їх штатної чисельності в рамках однієї посади відповідного фаху.
Зазначене вище, в комплексі, призводить до помилок у вирішенні питань практичної складової визначення кількісних показників організаційноштатної структури служб (підрозділів) персоналу.

Подальші дослідження у даному напрямку доцільно направити на обгрунтування підходів до визначення кількісних показників штатної чисельності служб (підрозділів) персоналу Збройних Сил України.

\section{Список використаних джерел і літератури}

1. Біла книга України: оборонна політика України/ щорічне видання 20102018 років - MOУ., 2010 - С. 18., 2011 - С. 23-26., 2012 - С. 15., 2013 - С. 33 , 2014 -C. 10-14., 2015 - C. 16., 2016-C. 8-10., 2017-C. 13-16., 2018-C. 20-25.

2. Воєнна доктрина України: затверджено Указом Президента України від 24.09.2015 № 555/2015 - АПУ,, 2015. - С. 10.

3. Указ Президента України від 06.06.2016 року № 240/2016"Про введення в дію Стратегічного оборонного бюлетеня" - АПУ., 2016.

4. Державна програма розвитку ЗС на період до 2020 року: введено в дію Указом Президента України від 22.03.2017 № 73/2017 - К., 2017.

5. Наказ Міністерства оборони України від 04.05.2016 №238 "Про затвердження Номенклатури посад для призначення військовослужбовців наказами по особовому складу" - МОУ., 2016.

6. Богунов С. О. Підходи до управління кар'єрою офіцерського складу / Богунов С. О., Герман Ю. М., Сакун О. Ю., Шупель Б. Н. // Військова освіта: Збірник наукових праць. -2002. - № 10, - С. 200-211.

7. Удосконалення Державної кадрової політики в ЗС України/О. Коваль// Державне управління та місцеве самоврядування. - 2017. - Вип. 4-C. 163-173.

8. Збройний конфлікт на Сході України: воєнно-історичний аспект (частина I - 2014 року). Наукова праця. К.:НУОУ, 2017. - 244 с. 


\section{References}

1. Bila knyha Ukrainy: oboronna polityka Ukrainy/ shchorichne vydannia 20102018 rokiv - MOU., 2010 - S. 18., 2011 - S. 23-26., 2012 - S. 15., 2013 - S. 33, 2014 - S. 10-14., 2015 - S. 16., 2016 - S. 8-10., 2017 - S. 13-16., 2018 - S. 20-25.

2. Voienna doktryna Ukrainy: zatverdzheno Ukazom Prezydenta Ukrainy vid 24.09.2015

№ 555/2015 - APU., 2015. - S. 10.

3. Ukaz Prezydenta Ukrainy vid 06.06.2016 roku № 240/2016 "Pro vvedennia v diiu Stratehichnoho oboronnoho biuletenia" - APU., 2016.

4. Derzhavna prohrama rozvytku ZS na period do 2020 roku: vvedeno v diiu Ukazom Prezydenta Ukrainy vid 22.03.2017 № 73/2017 - K., 2017.

5. Nakaz Ministerstva oborony Ukrainy vid 04.05.2016 № 238 "Pro zatverdzhennia Nomenklatury posad dlia pryznachennia viiskovosluzhbovtsiv nakazamy po osobovomu skladu" - MOU., 2016.

6. Bohunov S.O. Pidkhody do upravlinnia kar'ieroiu ofitserskoho skladu / Bohunov S.O., Herman Yu. M., Sakun O. Yu., Shupel B. N. // Viiskova osvita: Zbirnyk naukovykh prats. -2002 . - № 10. - S. 200-211.

7. Udoskonalennia Derzhavnoi kadrovoi polityky v ZS Ukrainy / O. Koval // Derzhavne upravlinnia ta mistseve samovriaduvannia. - 2017. - Vyp. 4-S. 163-173.

8. Zbroinyi konflikt na Skhodi Ukrainy: voienno-istorychnyi aspekt (chastyna I2014 roku). Naukova pratsia. K.: NUOU, 2017. - 244 s.

Dymenko, M.P., Ph.D., First Deputy Chief of Personnel Department of General Staff of the Armed Forces of Ukraine Ukraine (Kyiv)

\section{ANALYSIS OF THE FUNCTIONING OF THE SERVICES (UNITS) OF PERSONNEL OF THE ARMED FORCES OF UKRAINE IN 2011-2018 IN PEACETIME AND SPECIAL PERIOD}

The article analyzes the functioning of services (units) of personnel in the structure of the Armed Forces of Ukraine on the basis of their practical activity during 
2011-2018 in the conditions of peacetime and special period and their influence on the fulfillment of the Armed Forces of Ukraine by purpose. Structural changes of the military management bodies by years and the reform of the services (units) of personnel from the beginning of the ATO are presented, namely the creation of new organizational and staff structures, which were aimed at the formation of military management bodies, military units, units for the primary provision of protection of citizens and territorial the integrity of the state.

In addition, the problematic issues, miscalculations and causes that contributed to their occurrence are discussed. The main ways of solving these problems and directions of activity of services (units) of personnel in the course of their elimination are explained. It is analyzed how changes of organizational and staff structures of services (units) of personnel, reduction of their number to the indicators of minimum and sufficient expediency influenced the efficiency of personnel work on accounting issues and formation of rational proposals of efficient use of personnel by the team.

The expected results of the analysis are presented, which can help to resolve the issue of determining the quantitative indicators of the regular number of services (units) of personnel of the Armed Forces of Ukraine, for timely fulfillment of their staffing, training, support, and use of military personnel during the military service.

The general conclusions are made, which testify to the prevalence of manual mode of implementation of military personnel policy in the approaches of formation and determination of quantitative indicators of the staff and the list of services (units) of personnel. In this context, it is suggested that further research in this area should be directed to substantiate approaches to determining the quantitative indicators of the staffing level of the services (units) of personnel of the Armed Forces of Ukraine.

Keywords: military personnel policy, personnel work, services (units) of personnel, recruitment and placement, special period. 